CIHM

Microfiche

Series

(Monographs)
ICMH

Collection de microfiches (monographies)
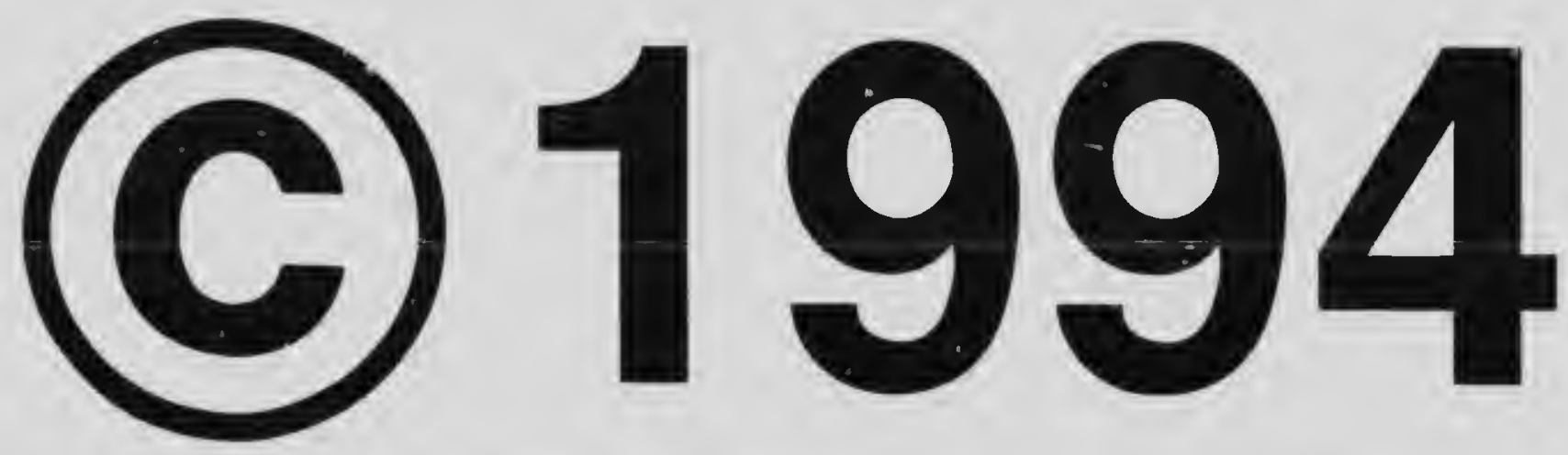
Technical and Bibliographic Notes / Notes techniques et bibliographiques

The Insiltute has atrempted to obtain the best original copy available for filming. Features of this copy which may be bibliographically unique, which may alter any of the images in the reproduction, or which may significan tly change the usual method of filming, are checked below.

Coloured covers/

Couver ture de couleur

Covers dameces/

Couver ture endommaghe

Covers restored and/or Iaminated/

Couverture restaurbe et/ou pelliculbe

Cover title missing/

Le titre de couverture manque

Coloured maps/

Cal tes giographiques en couleur

Coloured ink (i.e. other than blue or black)/

Encre de couleur (i.e. autre que bleue ou noire)

Coloured plates and/or illustrations/

Planches et/ou illustrations an couleur

r. Ind with other material/

: avec d'autres documents

Tight binding may cause shadows or distortion along in terior margin/

La reliure serrée paut causer de l'ombre ou de la distorsion le long de la marge intérieure

Blank leaves addod during restoration may appear within the text. Whenever possible, these have been omitted from filming/

II se peut que certaines pages blanches ajoutios lors d'une restauration apparaissent dans le texte. mais, lorsque cela itait possible. ces pages n'ont pas èté filmées.
L'Institut a microfilme le meilleur exemplaire qu'il lui a ete possible de se procurer. Les dttails de cet examplaire qui sont peut tre uniques du point de vue biblioerephique, qui peuvent modifier une image reproduite, ou qui peuvent exiger une modifiestion dans la mbihode normale de filmece sont indiquts ci-dessous.

\section{Coloured pages/}

Pages de couleur

Pages damaged/

Pages endommagies

Paqes restored and/or laminated/

Pages restaurbes et/ou pelliculces

( Pages discoloured, stained or foxed/

Pages dicolories, tachetées ou piquedes

Pages datached/
Pages détachtes

Showthrough/

Transparence

Quality of print varies/

Qualité inégale de l'impression

Continuous pagination/

Pagination continue

Includes index(es)/

Comprend un (des) index

Title on header taken from: /

Le titre de l'en-tlete provient:

[7 Title page of issuel

Page de titre de la livraison

Caption of issue/

Titre de départ de la livraison

Masthead/

Générique (périodiques) de la livraison

Additional comments:/ Pagination is as follows : p. 51-62.

Commentaires supplémentaires:

This item is filmed at the reduction ratio checked below/

Ce document est filmé au taux de réduction indiqué ci-dessous.

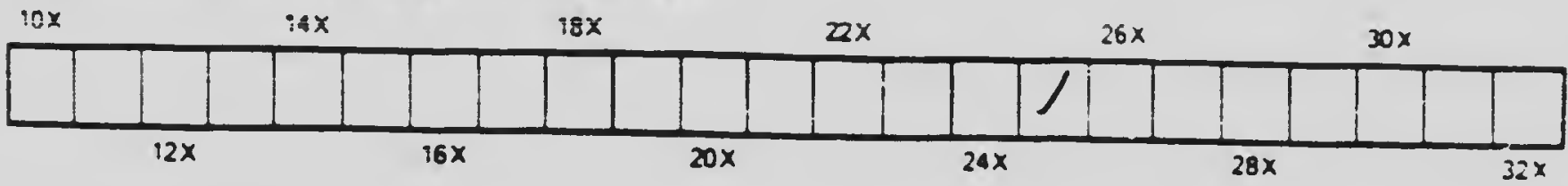


The copy filmed here hes been reproduced thenks to the generosity of:

\section{Dougias Library \\ Queen's University}

The imeges appeering here ere the best queiity possibie considering the condition end legibility of the originel copy end in keoping with the filming contract specificetions.

Originel copies in printed paper covers ere filmed beginning with the front cover end ending on the lest page with e printed of illustreted impression, or the beck cover when eppropriete. All other originai copies ere flimed beginning on the first page with o printed or lilustreted impression, and ending on the lest page with e printed or iilustrated impression.

The last recorded frame on eech microfiche shail contain the symbol $\longrightarrow$ Imeening "CON. TINUED"), or the symbol $\nabla$ (meaning "END"). whichever appiles.

Meps, piates, charts, etc., may be filimed ot different reduction retios. Those too lerge to be entireiy inciuded in one exposure ere filimed beginning in the upper loft hend corner, laft to right end top to bottom, as meny fremes os required. The foliowing diegrems iliustrete the method:
L'exempiaire flimb fut reproduit gresce is génórosito de:

$$
\begin{aligned}
& \text { Dougias Library } \\
& \text { Queen's University }
\end{aligned}
$$

Les imeges suiventes ont sts reproduites evec le plus grend soin, compte tenu de la condition ot de ie nottoto de l'exempioire flimb. ot en conformits ovec les conditions du contrat de filmege.

Les exempioires origineux dont ie couverture en popior est imprimbe sont filmbs on commençant por ie premier plat et en terminant soit par la dernidre pege qui comporte une empreinte d'impression ou d'iliustretion, soit par ie second plet, seion le ces. Tous ies eutres exempiaires originoux sont fiimbs en commençant par ia premidre pege qui comporte une empreinte d'impression ou d'illustration et en terminant par ie dernidre page qui comporte une teile empreinte.

Un des symboies suivants epparaitra sur ie dernidre image de cheque microfiche, seion ie ces: ie symbole $\longrightarrow$ signifie "A SUIVRE", ie symboie $\nabla$ signifie "FiN".

Les cartes, pianches, tabieaux, etc., peuvent être flimbs des taux de róduction différents. Lorsque le document est trop grend pour etre reproduit on un seui clich6, il est flimb partir de lengle supórieur gauche, de gauche a droite, et de hout en bes, on prenant le nombre d'images nocesseire. Les diagremmes suivants iliustrent ia móthode.

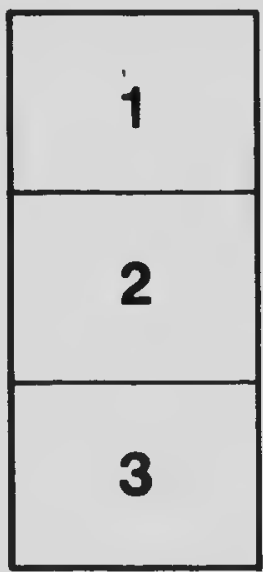

\begin{tabular}{|l|l|l|}
\hline 1 & 2 & 3 \\
\hline 4 & 5 & 6 \\
\hline
\end{tabular}




\section{Microcory MESOUTION TEST CHAHT}

IANSI and ISO IES? CMART No 2
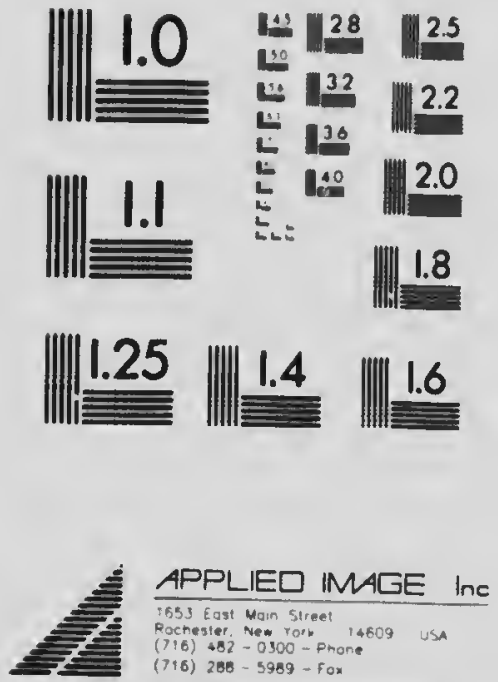


\section{UNIVFRSITY OF "ORONTO STUIII:S}

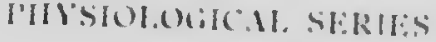

No. 11: THE: COMPARITHE VHLLE OF LARD AND

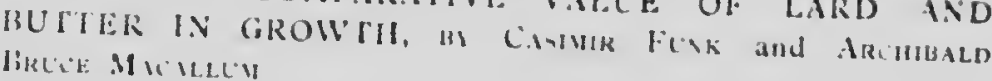

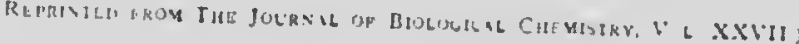

THE UNIVERSITY LIBR.IRY : PUBLISHED BY THE LIBR.ARIAN, WI6 


\title{
STUDIES ON GROWTH.
}

\section{THE COMPARATIVE VALUE OF LARD AND BUTTER FAT IN GROWTH.}

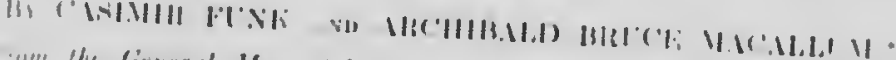

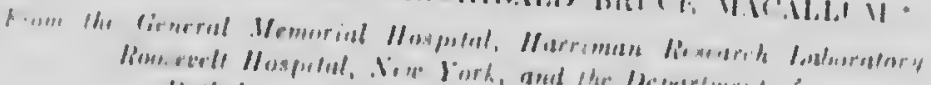

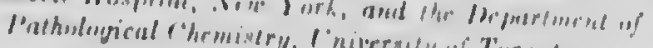 \\ illereivent
}

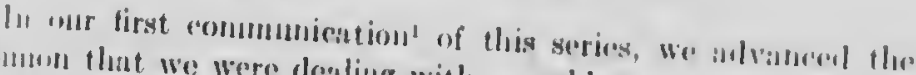

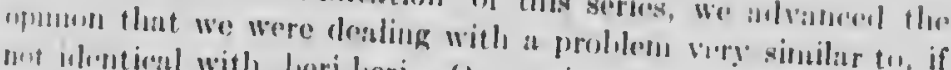

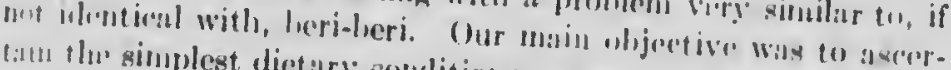

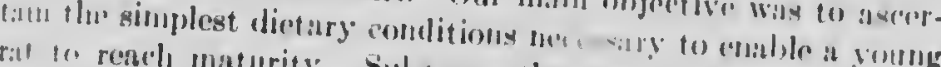

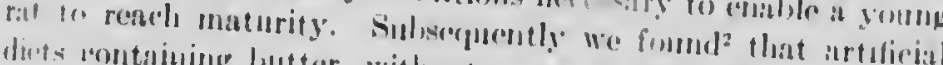

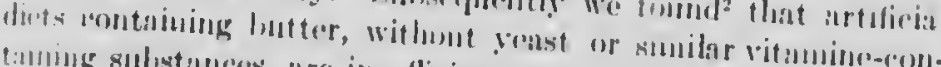

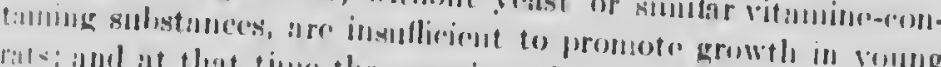

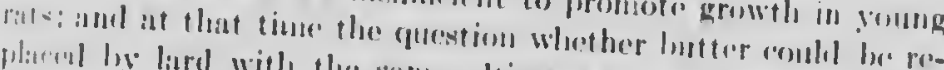

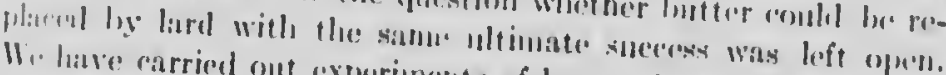

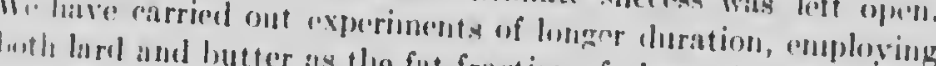

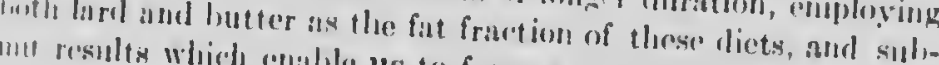

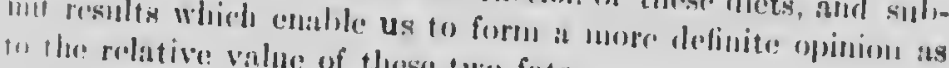
to llar rolative valure of threse two fats.

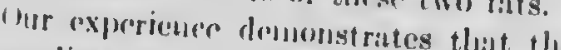

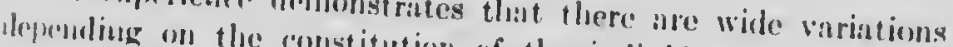

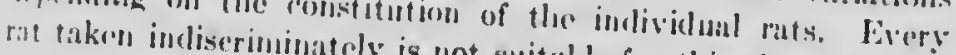
fi illatfer of fact in experin sutulle for this class of work.

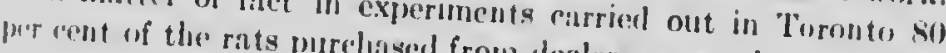
cunte of physionl defoets used from dealers were rejecterl on ace-

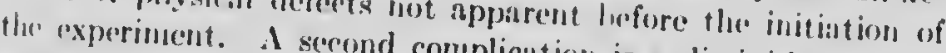
inn\% to infection, which follonglication is a diminished resist -

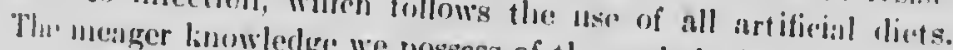

- Dinur fielluw in Mtelia:al linsearch.

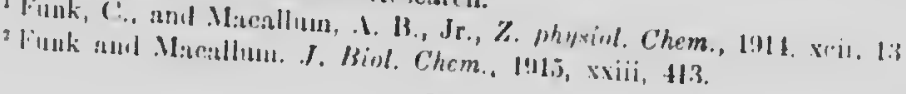




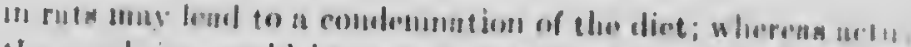

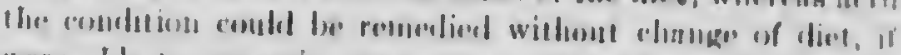

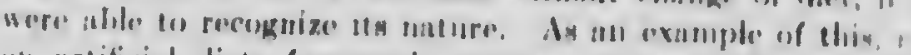

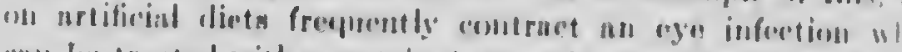

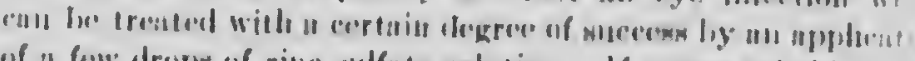

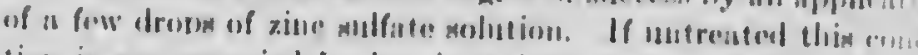

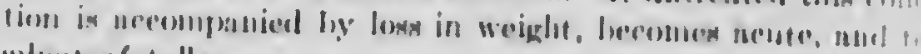
infuntex fatully.

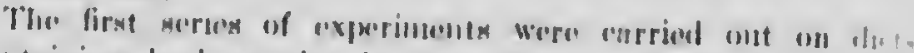

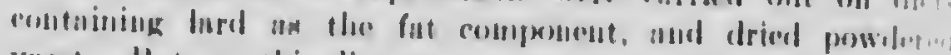

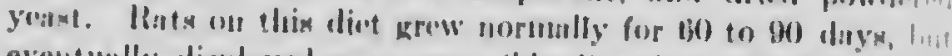

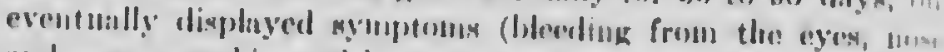

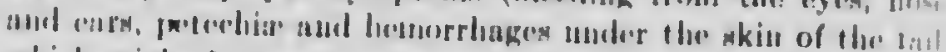

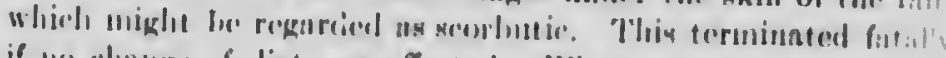

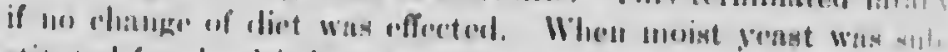

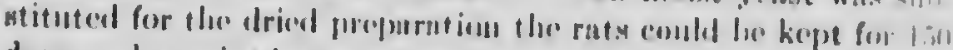

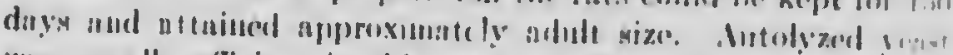

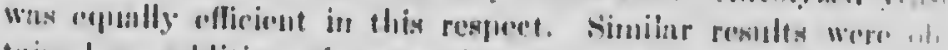

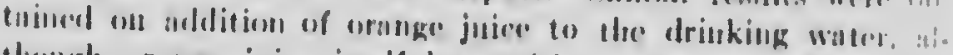

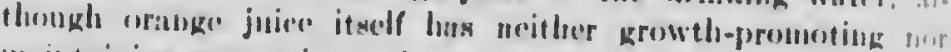

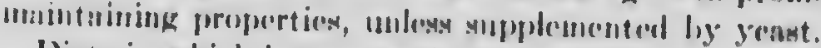

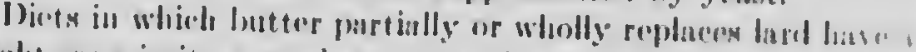
slight superionity over those contnining lard, which is insore thest can bo explained by the antiscorlutio propertios of the buthe

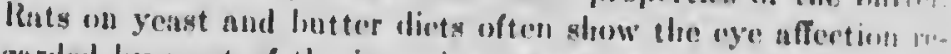
Rardenl hy most of the investigators as characteristic of dielitr: defreioncies, and we ure comvinewel that nowe of the artifind diets so far invegtignted con lo eompured with a mormal divelirs in its efficiency for growth. This deficiency introdures an indli.

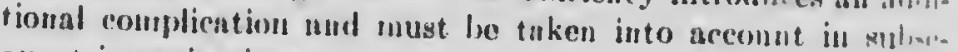
quent investigntions.

\section{EXP'RIMESTAL.}

The Inethods of preparing the diots were very much the situa" as those descrilied in our enrlier publications. The experinunts varied slightly as to their conditions in Nev: York and Tommen but the ultimate results were identical. The clasts and tallibs are representative of the different groups of experiments. 


\section{Hunk and A. H. Muerallum!}

Virpertmernt 1.

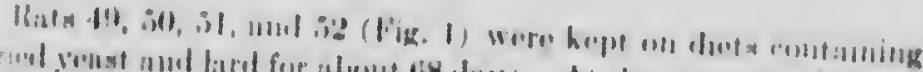

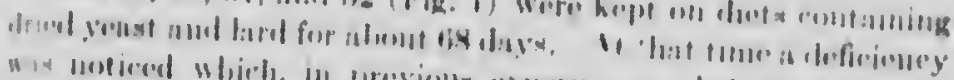

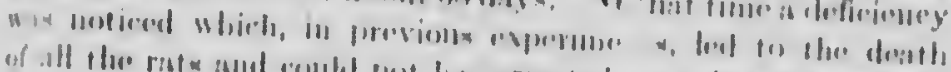

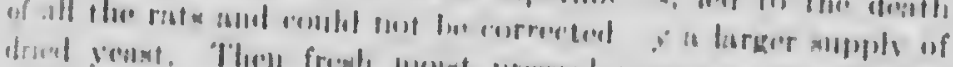

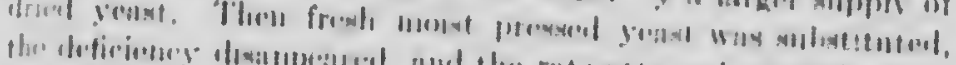

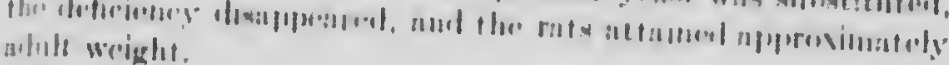

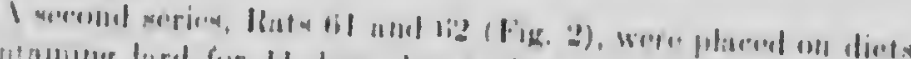

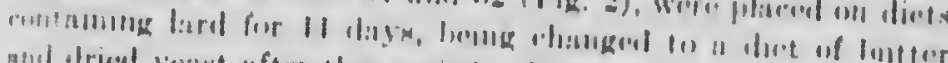

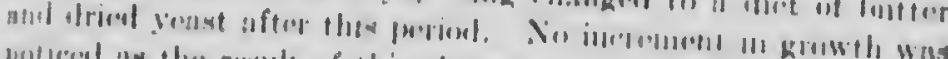

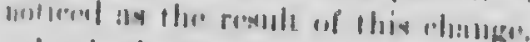

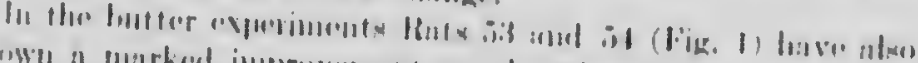

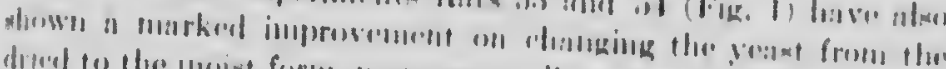

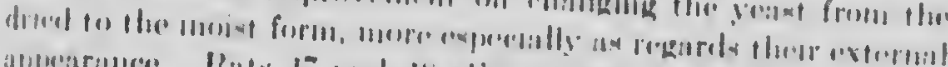

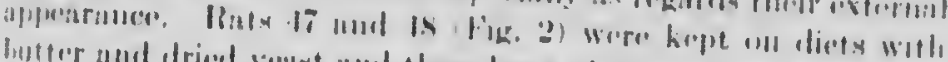

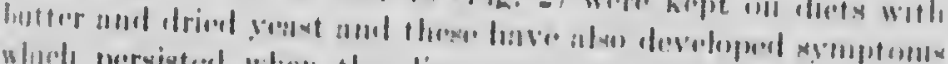

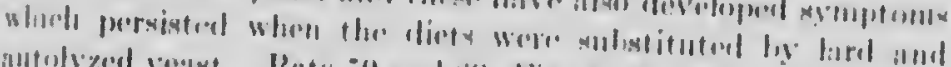

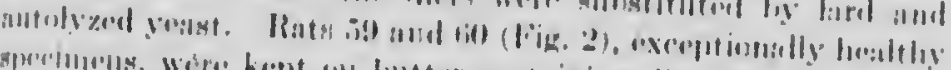

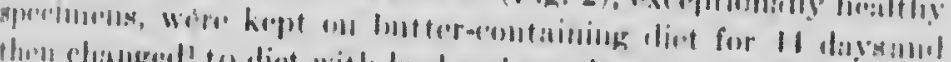

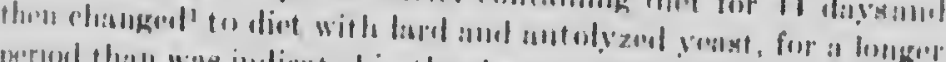

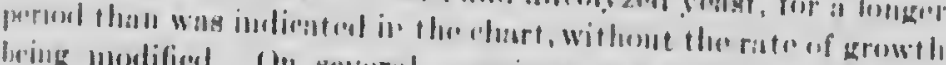

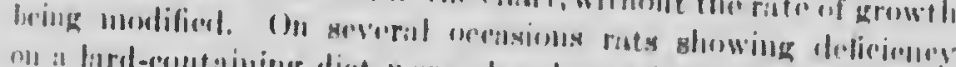

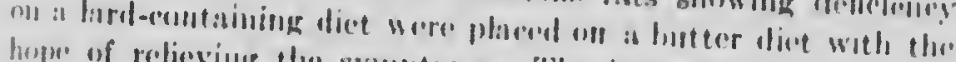

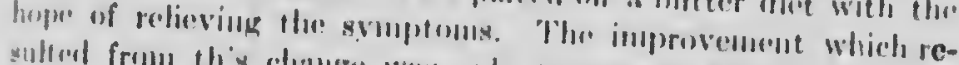

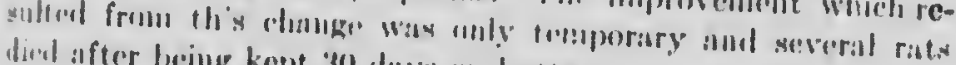

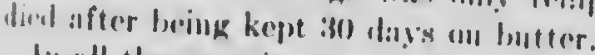

th all the experimeuts a markeof improvenent rosulted when

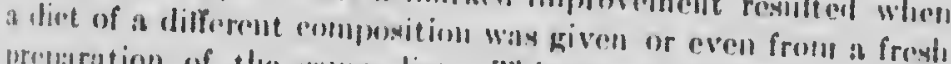
preplaration of the same dien. This might indieaten that the

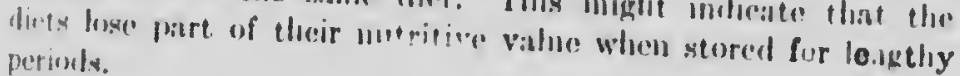
banin!

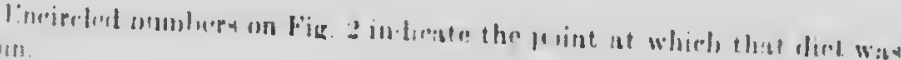




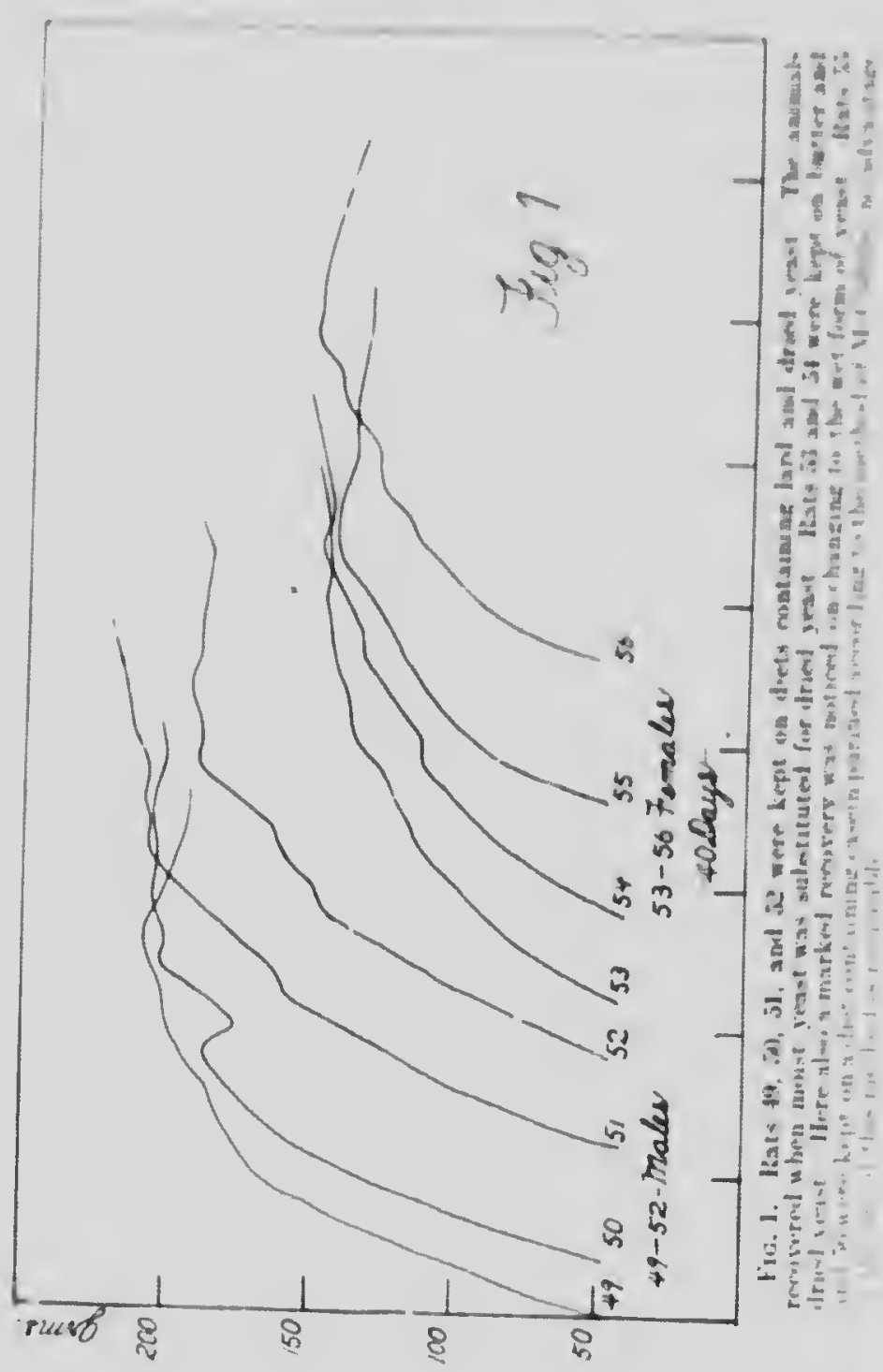




\section{Fink and I. II. Macallum}

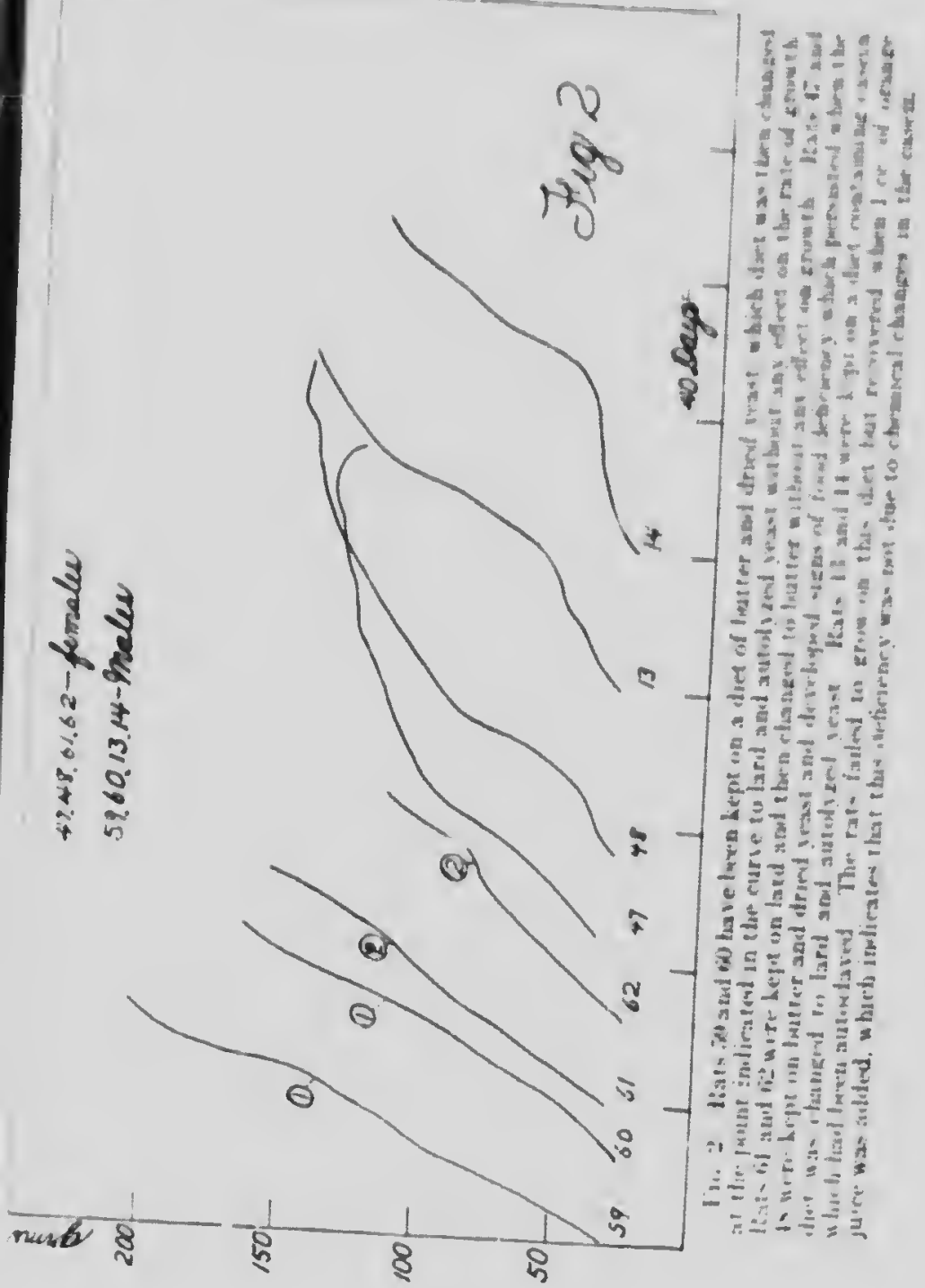


Dirtu (fill.).

\begin{tabular}{|c|c|c|}
\hline & b. & 2. \\
\hline Cino: & 23 & $\because$ \\
\hline Sugt $\ldots \ldots \ldots$ & 111 & 10 \\
\hline glurili ......... & in) & 27 \\
\hline I.nril. . . & iii) & $: 30$ \\
\hline Bult . . . . . . . . & $: 1$ & 3 \\
\hline Aknr. . . . . . & 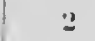 & 'I \\
\hline Yeust (Iry) . . . . . . . & $: 3$ & 6i \\
\hline Yenst. (annixt) equanl tu & & \\
\hline
\end{tabular}

\begin{tabular}{|c|c|c|}
\hline i. & 1 & .5 \\
\hline$\because 3$ & $3:=$ & 19 \\
\hline (1) & 10) & (1) \\
\hline 37 & 2.1 & 27 \\
\hline :31) & :3) & ;31) \\
\hline ii & ii & li \\
\hline$\because$ & 2 & 3 \\
\hline & $\begin{array}{l}1 \text { af alry } \\
\text { gru⿰t. }\end{array}$ & $\begin{array}{c}\text { B of } \\
\text { ary somat }\end{array}$ \\
\hline
\end{tabular}

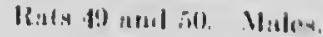
1) (is diand lowe

6! ! 48 " 4

(M-lint * "

\begin{tabular}{|c|c|c|c|c|c|c|}
\hline \multirow{2}{*}{ Bayn } & \multicolumn{2}{|c|}{ Woiklie. } & \multirow{2}{*}{$\begin{array}{c}\text { Avernges } \\
\text { fisen intithe } \\
\text { jure ol is }\end{array}$} & \multicolumn{2}{|c|}{ Wrisht } & \multirow{2}{*}{ 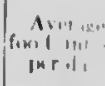 } \\
\hline & 49. & (i) & & iil & 52. & \\
\hline & $a m$ & $u m$. & culberisat & $y m$. & $u m$. & caleniex \\
\hline 0 & 41 & $11 i$ & & 11 & $11 i$ & \\
\hline 4 & Dij & ix & $\because 1$ & (i! & in & Ps :! \\
\hline 8 & 81 & $8 . j$ & 1,21 & 73 & 11,5 & NI :3 \\
\hline 12 & 96 & $l(x)$ & I11:2 & !1 & 5:! & (ii) : \\
\hline 16 & 101 & 1111 & $110 ; 7$ & $10 ! 2$ & 111 & $m$ \\
\hline $3(1)$ & 119 & 121 & $110: 3$ & 1111 & (1) & $1012:$ \\
\hline 31 & $1: 3: 3$ & $1: 5$ & 110.5 & $11 !$ & 110 & $111+i$ \\
\hline 38 & $111 ;$ & 1.81 & 1100 & $1: 3: 2$ & $1: 30$ & liki:: \\
\hline $3: 3$ & $(1, x)$ & $1 . j$ & 1110 & liks & $1: x$ & $I(x)<$ \\
\hline 36 & 1612 & 16,1 & IIn:! :3. & IIS & liks & $11: .1$ \\
\hline 40 & 17() & 171 & $111 \mathrm{li}$ & $1,1 ! 1$ & $1 \pi$ & Ilti \\
\hline 41 & $17: 3$ & 171 & 1113 & $1(i)$ & $1,01)$ & 11.11 \\
\hline IX & 177 & $1 S(1)$ & 1111 & Itiis & $\operatorname{lin}()$ & $11 \div$ \\
\hline 52 & 178 & 151 & 11,1 & 170 & 1.5 & 115 t \\
\hline 56 & IX:' & INS & $110 s$ & liti & liil & 14) i \\
\hline (in) & $1.5,5$ & $1 ! !$ & 113,8 & $17 x$ & 163 & $1131 \mathrm{i}$ \\
\hline 64 & 1Si; & $1: 0$ & TS & 17.1 & $\mid 1 i 1$ & "Iti" \\
\hline Gy & $1 S 1$ & IN: & ) & $1 ! ! !$ & $11 \mathrm{ij}$ & $101=$ \\
\hline 76 & $1 ! ! !)$ & $\because(M)$ & $11.5 !$ & & & (1): : \\
\hline S1 & $\because() 1$ & 2111 & 叫 & $3 x$ & 1') & II) \\
\hline $1(x)$ & $\because 17$ & 211,5 & $x . j 11$ & $\because(x) !$ & 119 & $1+111$ \\
\hline $1: 11$ & $\because(x)$ & $21 \%$ & 111.7 & 2111 & [1;i) & III:- \\
\hline 110 & 111: & 2116 & ili is & :11; & $1 \times 1 ;$ & inis \\
\hline $1,(1)$ & $1 ! !$ & $291: 3$ & $\therefore v$ & $2: 1$ & $(1 \div)$ & $\left(i i^{*}\right)$ \\
\hline
\end{tabular}

Rars il and Bis. Mitlos.

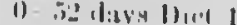

ij) liv $\triangle$.

(ii) !ा "

[I! li,il " 
lliele (fim.).

\begin{tabular}{|c|c|c|c|c|}
\hline$\ldots \ldots$ & & 2 & $y$ & 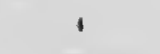 \\
\hline 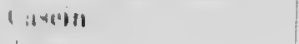 & $\because 2$ & $2: 2$ & $\because 3$ & $\ldots$ \\
\hline Sigur & I1) & 111 & lii & 10 \\
\hline Narrih & ; (1) & 27 & $2 ! !$ & $\because 7$ \\
\hline Mullar fitt .. & K & IV & is & is \\
\hline I.arit.... & $1: 2$ & I:2 & 12 & I: \\
\hline Filt ...... & 3 & 3 & i & ii \\
\hline $\begin{array}{l}\text { la:tr ... } \\
\text { lonisl folryel }\end{array}$ & :3 & $\frac{1}{1 i}$ & 2 & $\because$ \\
\hline 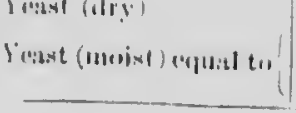 & & & $\begin{array}{c}1 \text { of } \\
\text { Iry l'itst. }\end{array}$ & $\begin{array}{c}3 \text { uf } \\
\text { 1]ry yo:เง|. }\end{array}$ \\
\hline
\end{tabular}

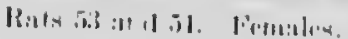

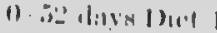
i.i) lis " $"$.
(i!) $\mid(x)$ " "
(1) I III " "

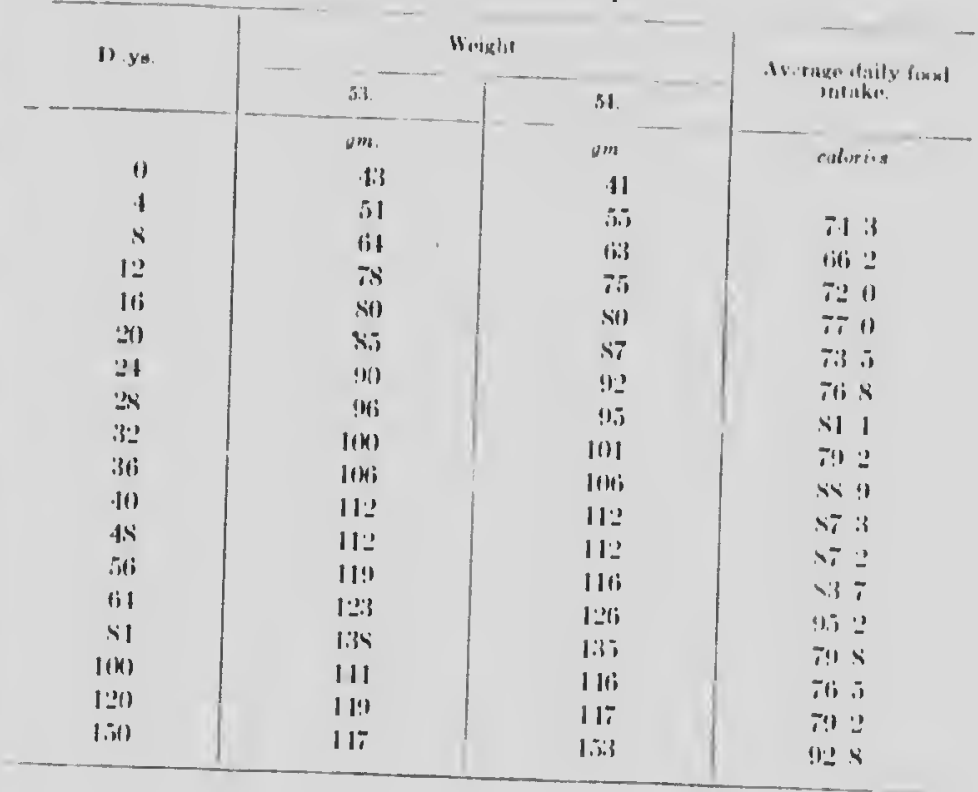


Divelo (rim.)

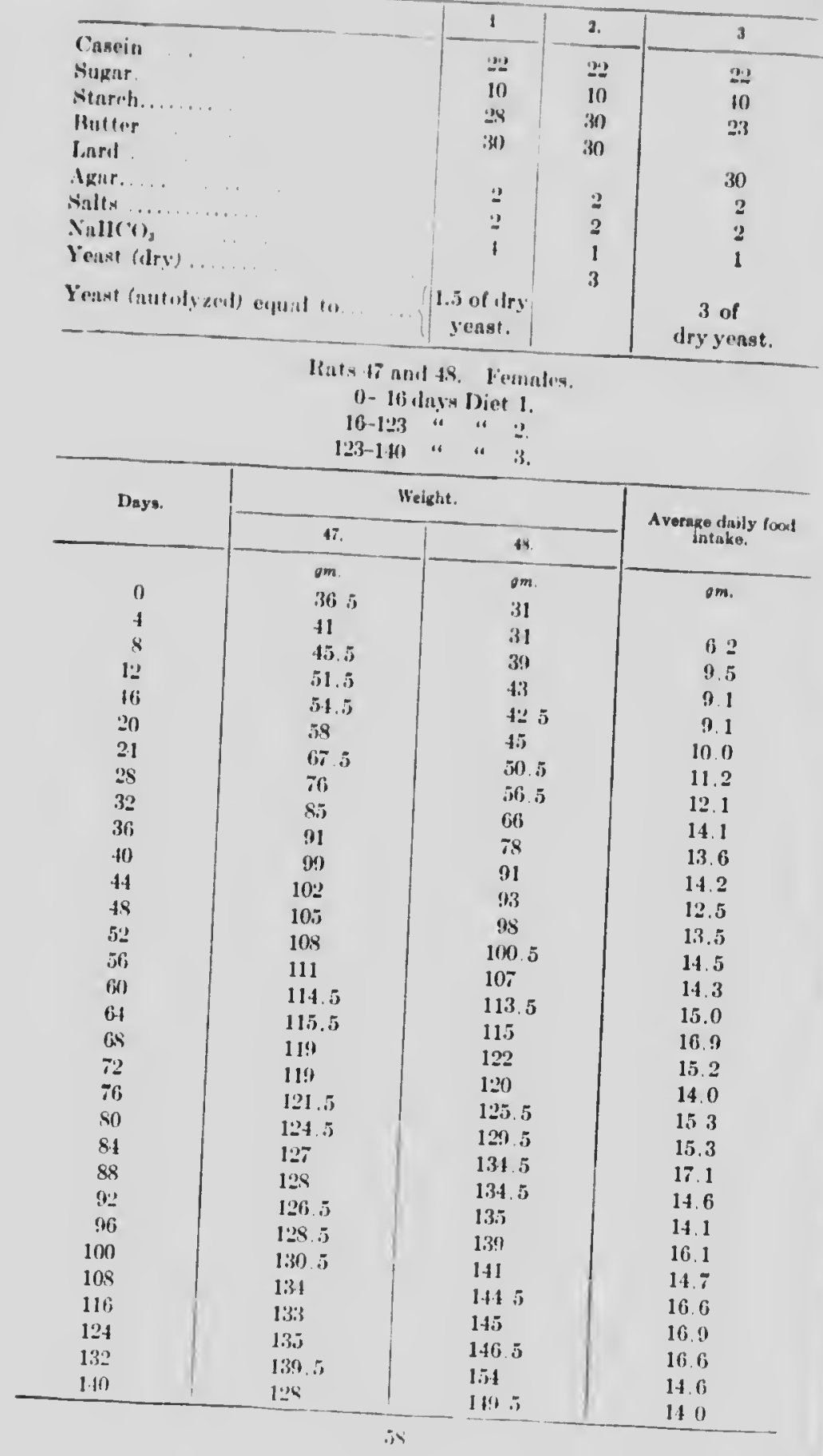


llirls (Gim.).

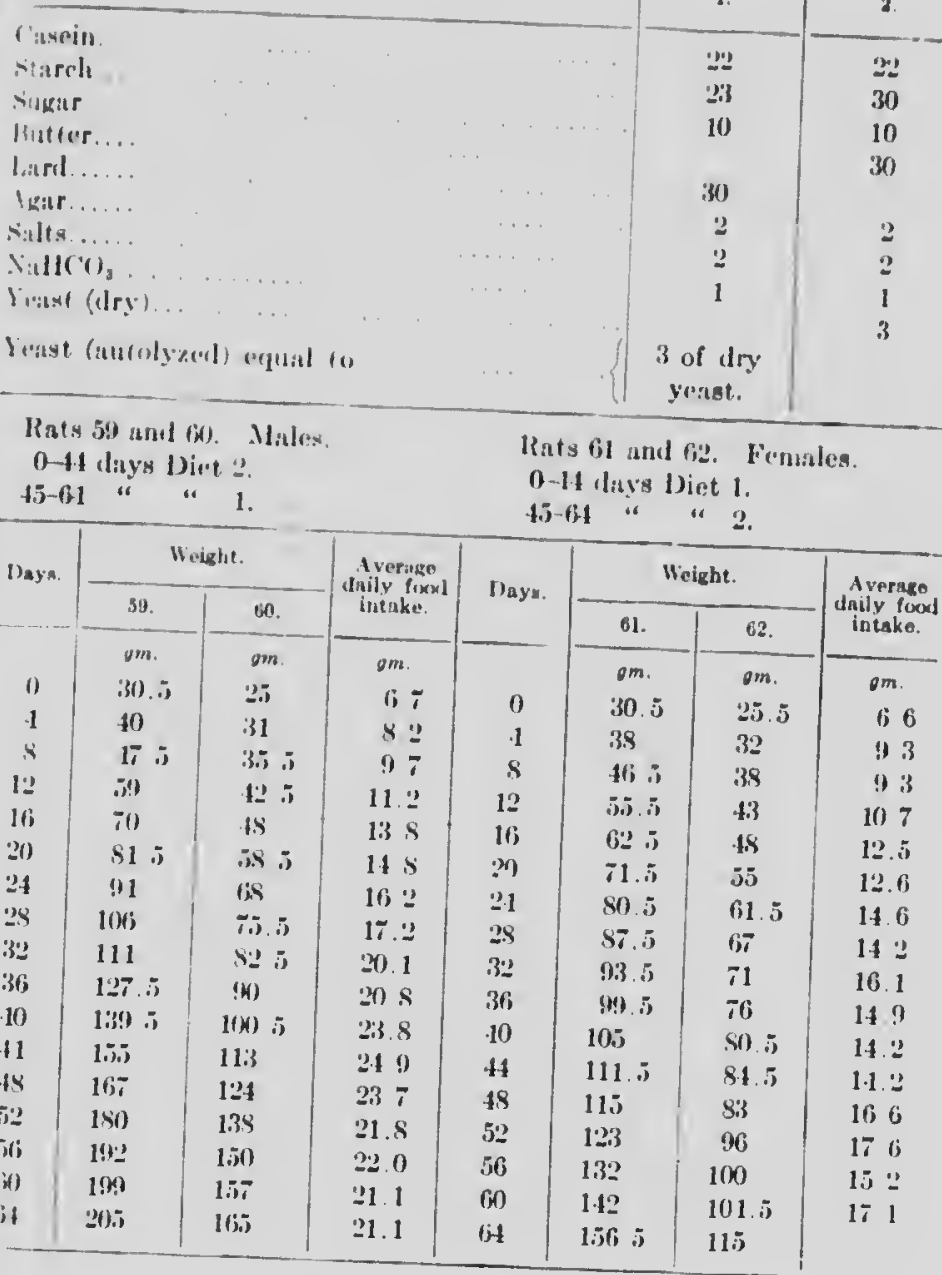

\section{Experiment II.}

The casein preparation used in this series was purified by washing, following the method of McCollun and Davis. In

${ }^{4}$ MrCollum, E. F. and D:1vis, M., J. Biol. Chem., 1915, xxiii. 231. 
this maper the authors chaius that purificution of cuscin hy beri. ing witle alcohol destroys some of the muino-ariels nul results if loss of its nutritive properties. The results in this case (IR:1) 55 aud so, Fig. 1) were identical with those which were obtuin. with ensein purified ly extruction with hot aleohol. This luttor methonl was used in purifying the cusein in the first cxperincent.

\begin{tabular}{|c|c|c|c|}
\hline & 8. & 2. & 3. \\
\hline 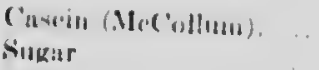 & ?'? & $2 ?$ & 22 \\
\hline Stiurelt $\ldots$ & 11) & 10 & 411 \\
\hline Larril & 27 & 39 & 27 \\
\hline N:ll & $: 311$ & 301 & 311 \\
\hline Ak:tr & 3 & i) & 18 \\
\hline Yount (Iry) & 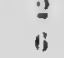 & 2 & 2 \\
\hline Vinst (moist) equal to. & & $\begin{array}{c}\text { tof } \\
\text { dry yonst. }\end{array}$ & $\begin{array}{c}\text { at of } \\
\text { Iry yeumet. }\end{array}$ \\
\hline
\end{tabular}

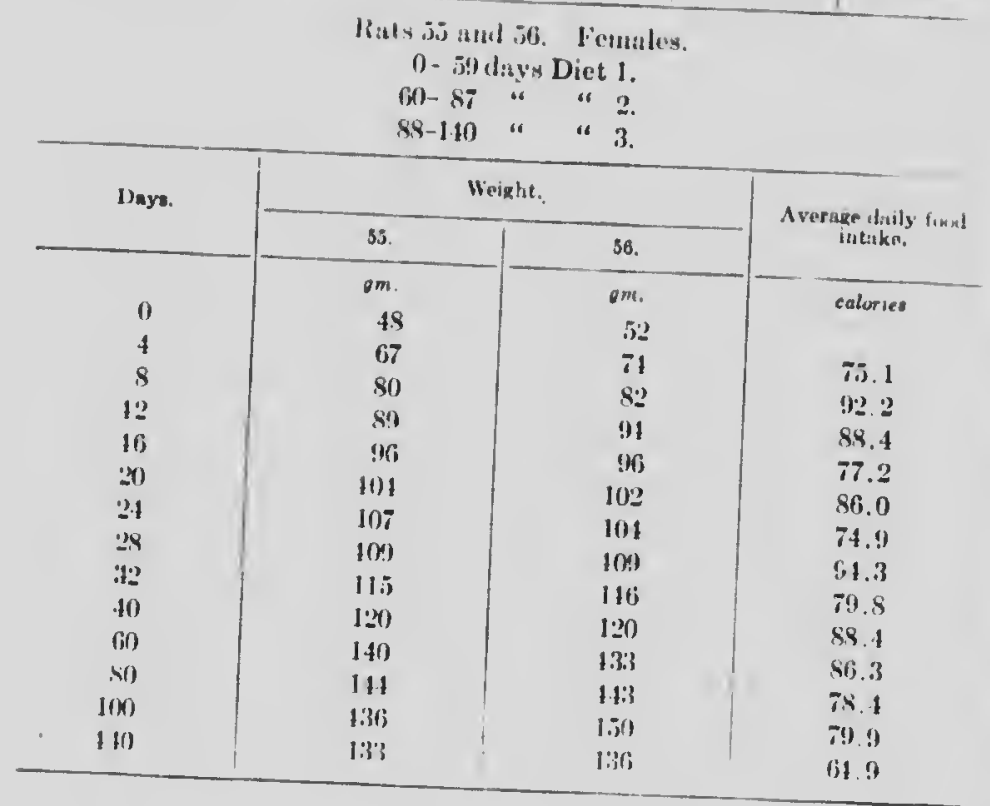




\section{Funk and A. B. Macallum}

Aleother series, of which Rate 13 and 14 (Fig. 2) are representa"Ives, received casein which had beril autorlaved for I hour at 15 pounds' pressurs, according to Me Colhum aud Davis. On this diet the rats failed to grow, hut after 28 days 1 ce. of fresh oriuge juice was added, and normal growth was resumed. It serous probahle that the impaired value of leated cascin is not due so much to the destruction of animu-seides as to the loss of its antiscorhutic properties.

hiels $(\mathrm{rim}$,

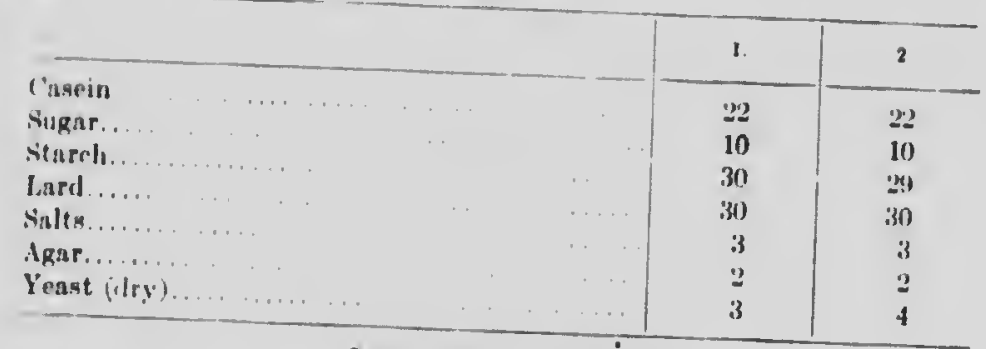

liats 13 and 14. Males.

0- 14 days Diet 1.

lif 90 " " 2

$28-100$ " 1 ce. orange juice.

\begin{tabular}{|c|c|c|c|}
\hline \multirow{2}{*}{ Days. } & \multicolumn{2}{|c|}{ Weight. } & \multirow{2}{*}{$\begin{array}{l}\text { A vernge daily food } \\
\text { intake. }\end{array}$} \\
\hline & 13. & 14. & \\
\hline 0 & $\begin{array}{l}\text { om. } \\
33.3\end{array}$ & $\begin{array}{l}\text { gm. } \\
27.2\end{array}$ & $\mathrm{om}$. \\
\hline 4 & 40.1 & 33.7 & 6.2 \\
\hline 8 & 41.4 & 37.1 & 6.0 \\
\hline 12 & 44.6 & 39.8 & 7.1 \\
\hline 16 & 46.4 & 39.4 & 7.9 \\
\hline 20 & 50.6 & 41.4 & 7.2 \\
\hline 24 & 54.3 & 42.0 & 8.1 \\
\hline 29 & ㄷ․ 6 & 41.5 & 6.5 \\
\hline 32 & 5i5. 1 & 42.0 & 4.7 \\
\hline 36 & 63.1 & 47.0 & 8.2 \\
\hline 40 & 62.1 & 44.0 & 6.8 \\
\hline 44 & 70.8 & 46.2 & 8.4 \\
\hline 48 & 77.1 & 46.2 & 10.6 \\
\hline 52 & 87. 1 & 51.8 & 12.2 \\
\hline
\end{tabular}




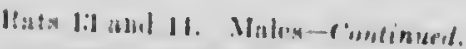

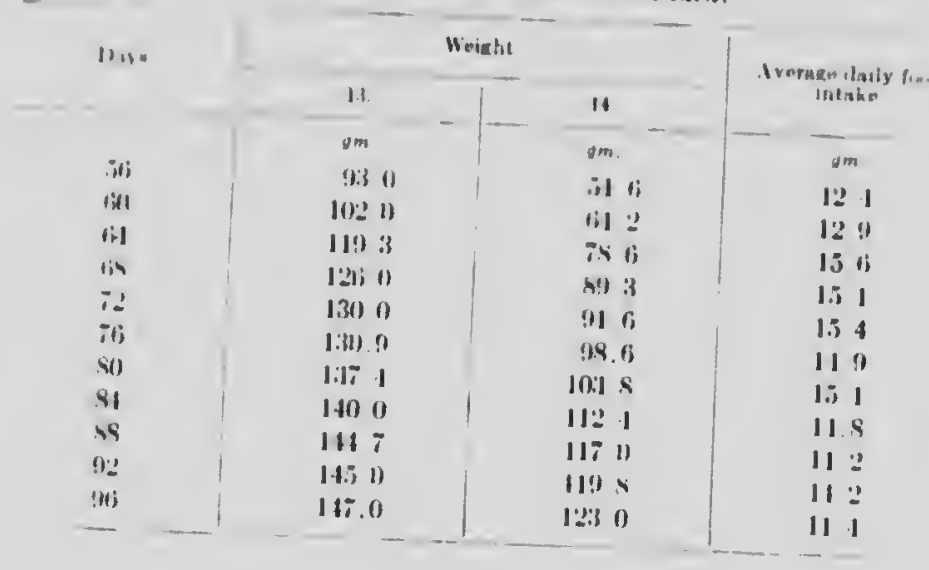

\section{SUMMIEY.}

The failure of rats to grow on a litrl and yeust diet is partialls dee the development of scorbutic symptoms. These can l. relieverd to a marked degree by using moist instead of dried yees and still more so ly meing moist youst and butter. Even in thin sintere me the existing deficioncies arre not entircly correctenl.

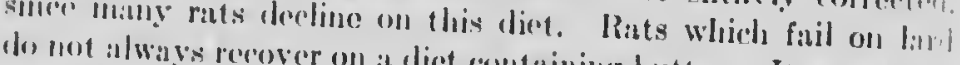
possiblo that youst on an at diet containing hatter. It secms alsen perhapsother constitucents, is of its high content in purines, atiul

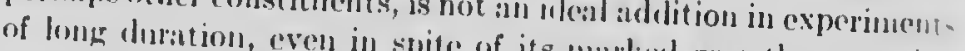
power. The impared untritive of its marked growth-pronotimg

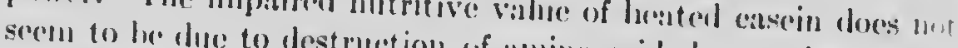
of vitamines. 


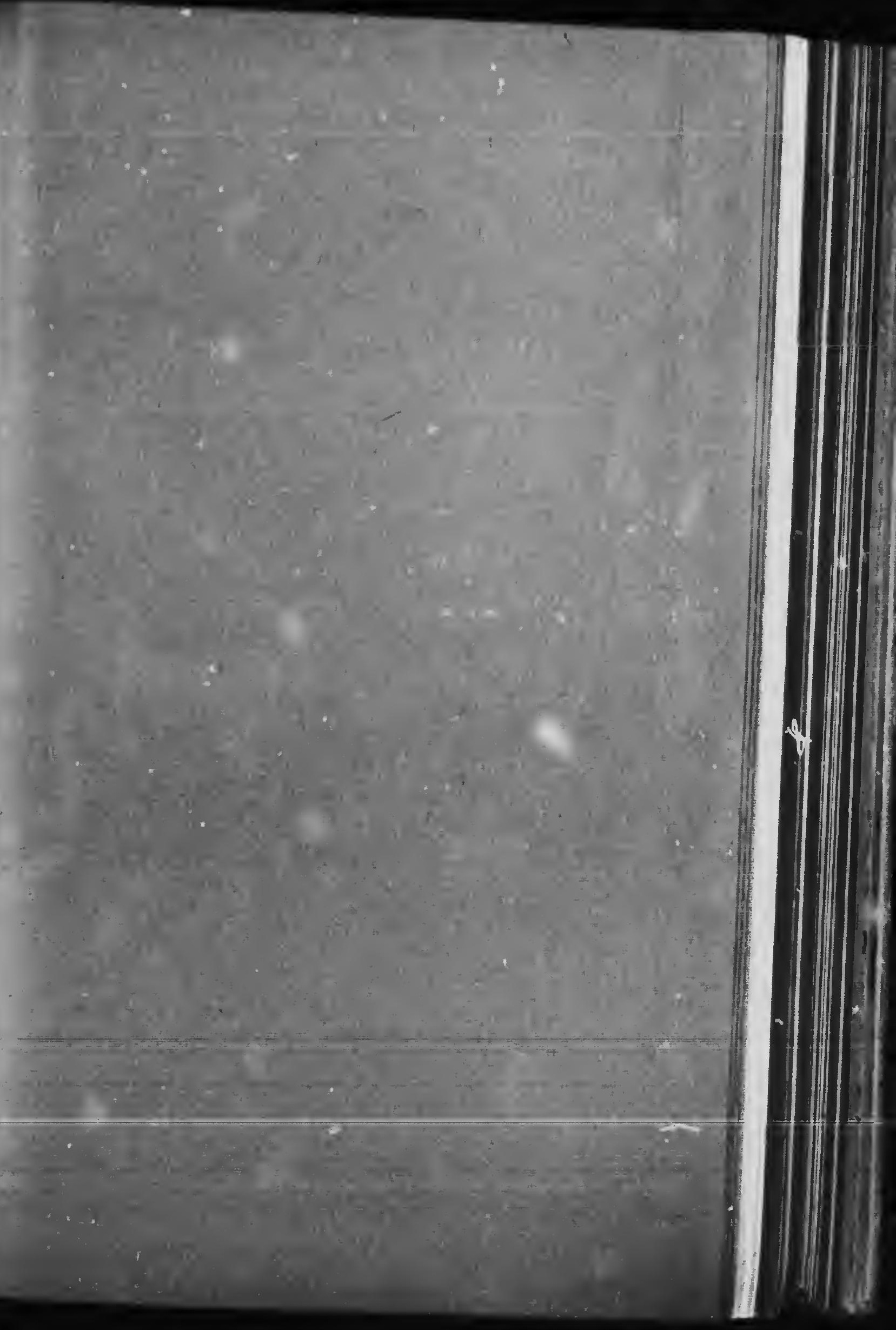




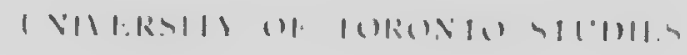

$111+111,1,11>1+11=$

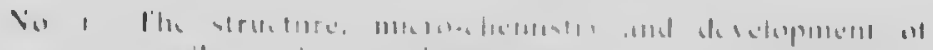

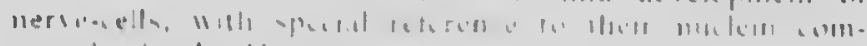

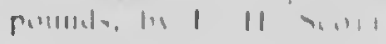

"5"

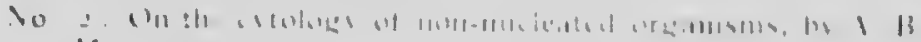
W11 11114

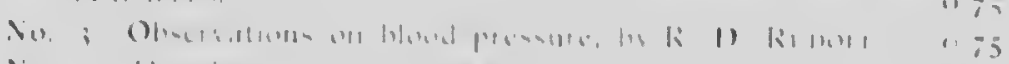

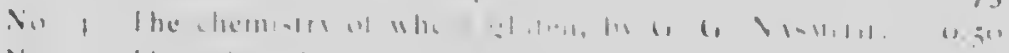

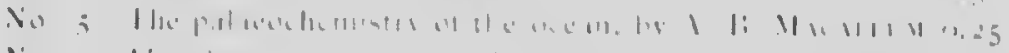

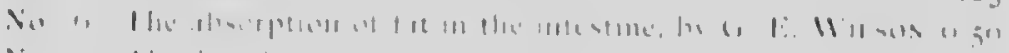

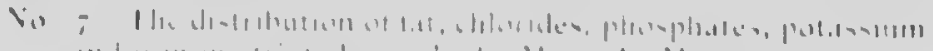

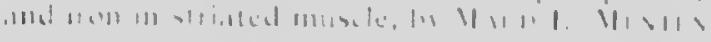

(1). 2.5

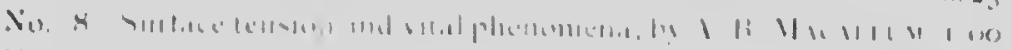

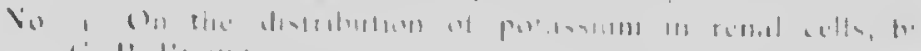
C'. I' liknt?

1125

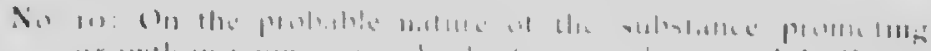

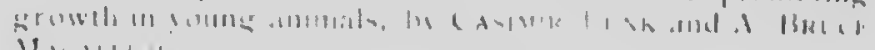
II 1111,1

13. 25

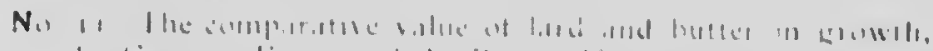

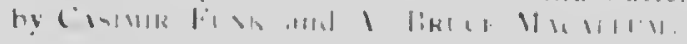

1). $\therefore$

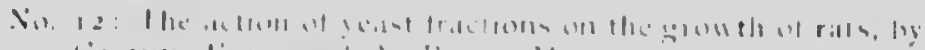

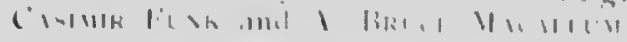

0. 25

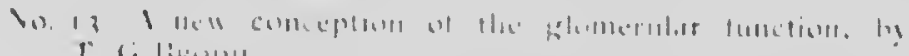
I (i likill

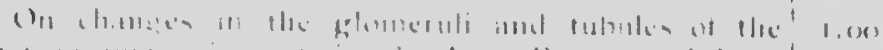

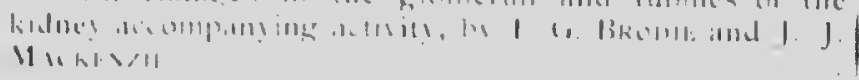

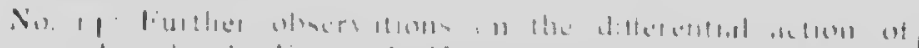

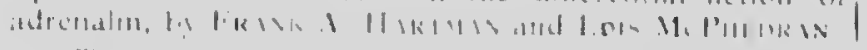

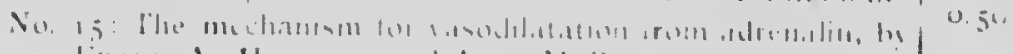

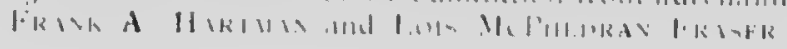




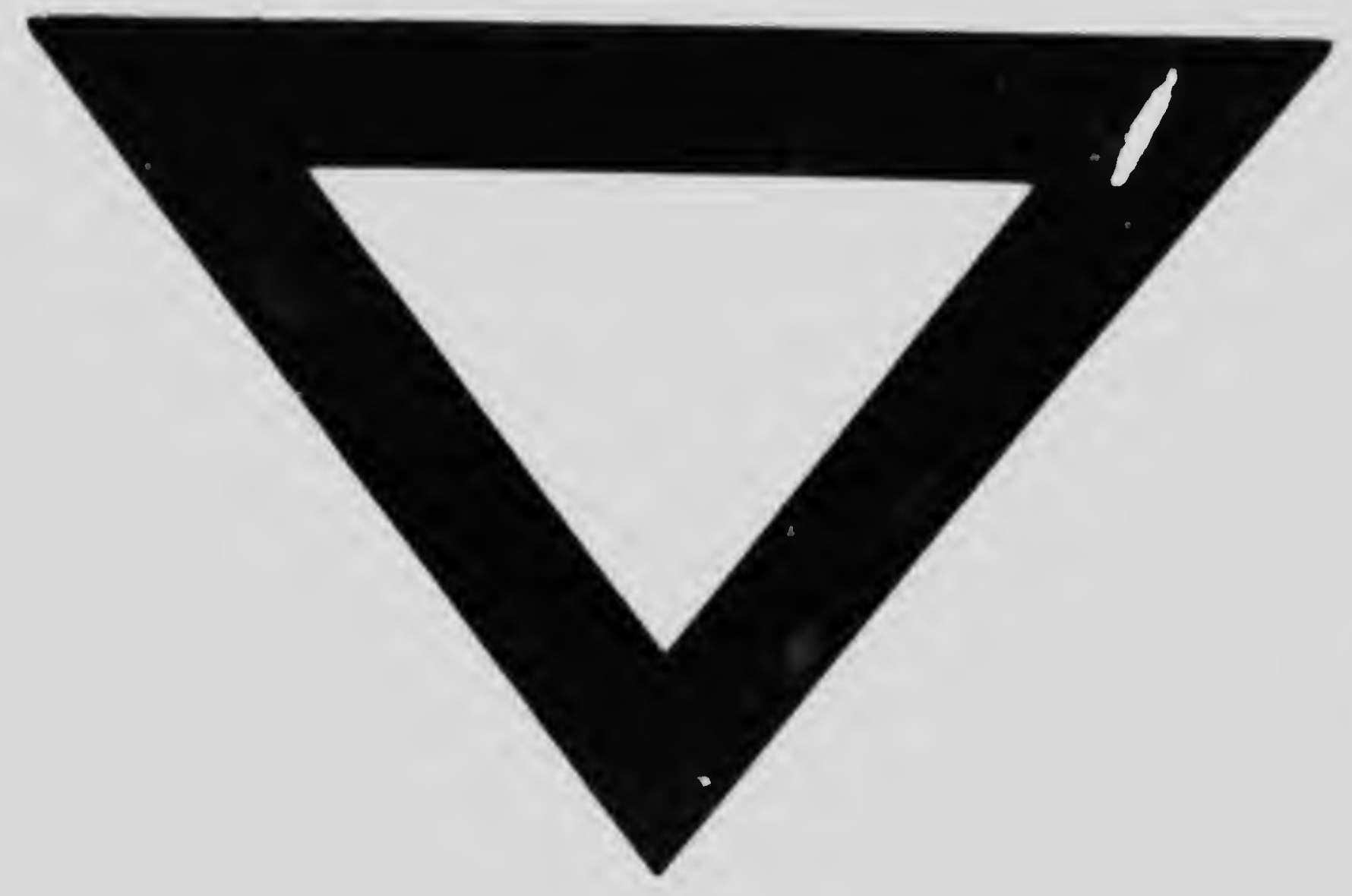

